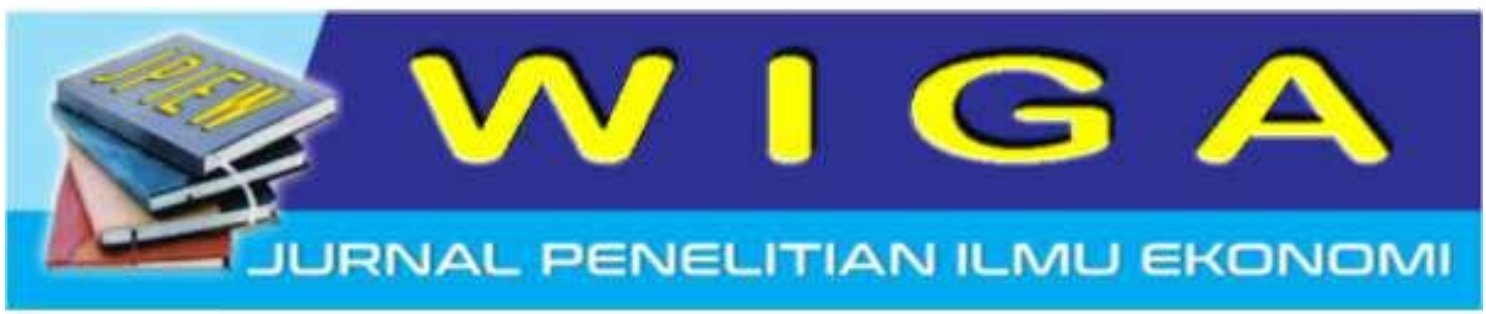

\title{
Analisis Rasio Sebagai Dasar Pengukuran Kinerja Keuangan Pada Koperasi Simpan Pinjam Syariah BMT UGT Sidogiri
}

\author{
Helmi Agus Salim \\ STIE Mandala Jember \\ helmi@stie-mandala.co.id \\ Amiroh Nurbailah \\ STIE Mandala Jember
}

\begin{abstract}
Abstrak
Koperasi simpan pinjam Syariah BMT UGT Sidogiri adalah lembaga keuangan yang kegiatannya mengumpulkan dana dari anggota dan menyalurkannya melalui sistem keuangan islam. Sumber dana ini berasal dari dan untuk anggota koperasi,. Dengan banyaknya kompetitor dan ketidakpastian kondisi ekonomi di Indonesia, berpengaruh pada ketidakstabilan pada sektor keuangan. Oleh karena itu perlu adanya penilaian terhadap kinerja keuangan pada koperasi simpan pinjam syariah BMT UGT Sidogiri menggunakan analisis terhadap kinerja keuangan dengan menggunakan analisa rasio. Penelitian ini menggunakan perhitungan yang berasal dari data laporan keuangan. Sementara itu, alat analisis yang digunakan pada penelitian ini menggunakan analisa rasio yang meliputi rasio likuiditas, rasio solvabilitas, dan rasio profitabilitas.Secara keseluruhan analisis ini telah dilaksanakan dari tahun 2014-2017 dan memiliki rasio yang cukup baik kecuali pada rasio kas. Tidak dapat dipungkiri rasio kas mengalami penurunan dikarenakan analisa kas dan setara kas yang dimiliki koperasi tidak cukup dalam membayar hutang lancarnya. Dimana koperasi simpan pinjam syariah BMT UGT Sidogiri mampu menghasilkan laba bersih yang maksimal yang berasal dari jumlah pinjaman yang disesuaikan dengan jenis usaha koperasi simpan pinjam.
\end{abstract}

\section{Kata kunci : Rasio Keuangan, Lembaga Keuangan, Koperasi simpan pinjam syariah BMT UGT Sidogiri}

\begin{abstract}
Saving and loan cooperative Syariah BMT UGT Sidogiri is one of financial institutions in which its activity is to collect fund from the members and distribute it through the mechanism of the islamic financial services business. It is from and for cooperative members, or even the candidate ones. With more and more competitors and the uncertain of the economic condition of
\end{abstract}


indonesia affects unstable condition in its financial sector. To know that financial condition, needed appraisal toward Saving and loan cooperative Syariah BMT UGT Sidogiri financial performance by applying analysis against financial performance through the financial ratios.This observation using calculation concern with the data in the form of financial report. Meanwhile, the analysis tool which is used in this observation is financial ratios which covers liquidity ratio, solvency ratio, and profitability ratio.Overall from 2014-2017 analysis which is done produces good enough ratio except cash ratio analysis. That gains the smallest ratios, because in analyzing it conceptually does not invoive credit accounts, where in this Saving and loan cooperative Syariah BMT UGT Sidogiri the greatest wealth is got from credit accounts in accordance with the type of cooperative business namely Saving and loan cooperative.

\section{Keywords: Financial Ratio, Work of Finance,Saving and loan cooperative Syariah BMT UGT Sidogiri}

\section{PENDAHULUAN}

Perusahaan pada intinya didirikan untuk mendapatkan keuntungan atau laba yang mana keuntungan atau laba tersebut diperoleh dari selisih antara pendapatan terutama dari hasil penjualan barang / jasa yang dihasilkan dengan biaya - biaya yang digunakan untuk menghasilkan barang / jasa tersebut. Untuk mencapai tujuan pokok perusahaan tersebut, tentunya banyak faktor yang mempengaruhi,diantaranya adalah masalah keuangan yang dapat dikatakan merupakan salah satu hal yang sangat krusial dan harus diperhatikan untuk dapat tercapainya tujuan pada perusahaan secara maksimal. Untuk mengetahui tingkat pencapaian tujuan perusahaan, maka secara periodik perusahaan melakukan pengukuran kinerja yang telah di capai atau di peroleh dengan menggunakan instrument, yaitu analisis laporan keuangan.

Laporan keuangan merupakan alat yang sangat penting untuk memperoleh informasi mengenai posisi keuangan perusahaan dan hasil usaha yang telah dicapai oleh suatu perusahaan. Salah satu bentuk informasi yang di gunakan untuk mengetahui kondisi dan perkembangan suatu perusahaan adalah laporan keuangan yang dilaporkan setiap akhir periode sebagai laporan pertanggungjawaban atas pengelolaan suatu perusahaan. Analisis laporan keuangan dalam banyak hal mampu menyediakan indikator penting yang berhubungan dengan keadaan keuangan perusahaan, sehingga dapat dipakai sebagai alat pertimbangan dalam pengambilan keputusan keuangan sekaligus menggambarkan kinerja pada perusahaan.

Penilaian kinerja pada aspek keuangan perusahaan lebih sering menggunakan teknik analisis rasio keuangan. Dengan analisa rasio keuangan akan dapat diketahui berapa tingkat likuiditas, solvabilitas, aktivitas, dan profitabilitas/rentabilitas yang dimiliki oleh suatu perusahan. Tingkat Likuiditas adalah menunjukkan sejauh mana kemampuan perusahaan dalam memenuhi kewajiban jangka pendeknya yang segera jatuh tempo. Tingkat likuiditas ini berguna bagi kreditur yang akan memberikan kredit jangka pendek. Sedangkan tingkat solvabilitas menunjukkan sejauh mana kemampuan perusahaan dalam memenuhi seluruh kewajibannya, yaitu kewajiban jangka pendek maupun jangka panjang. Tingkat aktivitas, menunjukkan sejauh mana kemampuan dan efektifitas manajemen perusahaan dalam mengelola sumber sumber yang dimilikinya. Tingkat rentabilitas menunjukkan sejauh mana kemampuan perusahaan dalam menghasilkan laba dengan modal yang 
dimilikinya. Hal ini sangat penting mengetahui efisiensi dari suatu perusahaan.

Berdasarkan latar belakang diatas, maka permasalahan yang diajukan dalam penelitian ini adalah "Bagaimana kinerja keuangan Koperasi Simpan Pinjam Syariah BMT UGT Sidogiri jika diukur dengan menggunakan rasio keuangan?”.

\section{TINJAUAN PUSTAKA}

\section{Laporan Keuangan}

Laporan keuangan adalah hasil dari proses akuntansi yang dapat digunakan sebagai alat untuk mengkomunikasikan data keuangan atau aktivitas perusahaan kepada pihak - pihak yang berkepentingan (Hery, 2015:3).

\section{Tujuan Laporan Keuangan}

Seperti diketahui bahwa setiap laporan keuangan yang dibuat sudah pasti memiliki tujuan tertentu. Tujuan khusus laporan keuangan adalah menyajikan posisi keuangan, hasil usaha, dan perubahan posisi keuangan lainnya secara wajar dan sesuai dengan prinsip - prinsip akuntansi yang berlaku umum. Sedangkan tujuan umum laporan keuangan menurut Hery (2015:5) adalah sebagai berikut:

a. Memberikan informasi yang terpercaya tentang sumberdaya ekonomi dan kewajiban perusahaan

b. Memberikan informasi yang terpercaya tentang sumber kekayaan bersih yang berasal dari kegiatan usaha dalam mencari laba;

c. Memungkinkan untuk menaksir potensi perusahaan dalam menghasilkan laba;

d. Memberikan informasi yang diperlukan lainnya tentang perubahan aset dan kewajiban;

e. Mengungkapkan informasi relevan lainnya yang dibutuhkan oleh para pemakai laporan.

Bentuk dan Susunan Laporan Keuangan

a. Neraca
Menurut Hery (2015:55) Neraca melaporkan aset, kewajiban, dan ekuitas pemegang saham pada suatu tanggal tertentu. Dengan menyediakan informasi mengenai aset, kewajiban, dan ekuitas pemegang saham, neraca dapat dijadikan sebagai dasar untuk mengevaluasi tingkat likuiditas, struktur modal, dan efisiensi perusahaan, serta menghitung tingkat pengembalian aset atas laba bersih.

\section{b. Laporan Laba Rugi}

Menurut Hery (2015:30) laporan laba rugi adalah laporan yang menyajikan ukuran keberhasilan operasi perusahaan selama periode waktu tertentu. Menurut James G. Van Horne (2014:154), laporan laba rugi adalah laporan yang meringkas pendapatan dan biaya perusahaan selama suatu periode waktu tertentu, biasanya untuk periode satu tahun atau kuartalan.

\section{c. Laporan Arus Kas}

Laporan ini menggambarkan tentang perputaran uang (kas dan bank) selama periode tertentu, misalnya bulanan dan tahunan. Laporan arus kas terdiri dari kas untuk kegiatan operasional dan kas untuk kegiatan pendanaan.

\section{Analisis Rasio Keuangan}

Rasio keuangan adalah angka yang diperoleh dari hasil perbandingan antara satu pos laporan keuangan dengan pos lainnyayang mempunyai hubungan yang relevan dan signifikan (Hery , 2015:138). Kasmir (2014:104) mendefinisikan "Rasio keuangan merupakan kegiatan membandingkan angka - angka yang ada dalam laporan keuangan dengan cara membagi satu angka dengan angka lainnya. Perbandingan dapat dilakukan antara satu komponen dengan komponen dalam satu laporan keuangan atau antar komponen yang ada diantara laporan keuangan. Kemudian angka yang diperbandingkan dapat berupa angka - angka dalam satu periode maupun beberapa periode". 
Kinerja Keuangan Kinerja keuangan adalah suatu analisis yang dilakukan untuk melihat sejauh mana suatu perusahaan telah melaksanakan dengan menggunakan aturan - aturan pelaksanaan keuangan secara baik dan benar (Fahmi , 2012:2).

Tahap - Tahap Dalam Menganalisis Kinerja Keuangan

Penilaian kinerja setiap perusahaan berbeda - beda, karena itu tergantung kepada ruang lingkup bisnis yang dijalankannya. Menurut Fahmi (2012:3) ada 5 (lima) tahap dalam menganalisis kinerja keuangan suatu perusahaan secara umum, yaitu:

- Melakukan review terhadap data laporan keuangan;

- Melakukan perhitungan;

- Melakukan perbandingan terhadap hasil hitungan yang telah diperoleh;

- Melakukan penafsiran (interpretation) terhadap berbagai permasalahan yang ditemukan;

- Mencari dan memberikan pemecahan masalah (solution) terhadap berbagai permasalahan yang ditemukan.

\section{Kerangka Pemikiran}

Kerangka pikir dalam peneliltian ini adalah dengan menggunakan data - data yang diperoleh dari perusahaan, berupa laporan keuangan perusahaan laba rugi dan neraca, kemudian data - data tersebut di analisis dengan menggunakan analisis rasio. Setelah di ketahui masing - masing rasio, maka akan dilakukan interpretasi hasil pengolahan data tersebut untuk mengetahui kinerja.

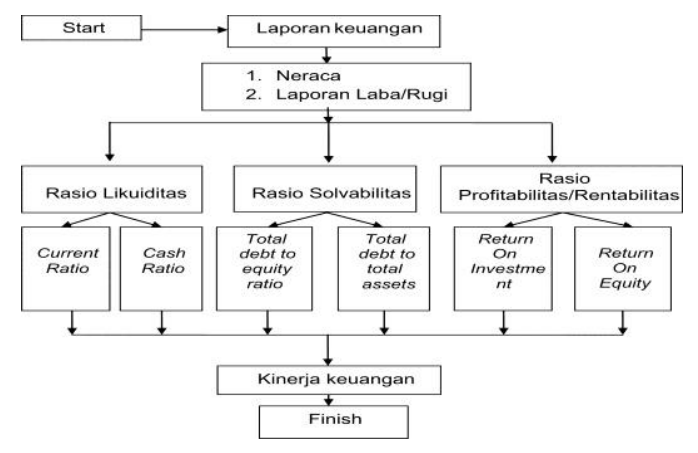

Gambar: Kerangka Pemikiran

Bagian metodologi berisi pendekatan yang digunakan dalam menghasilkan artikel ilmiah.Khususuntukartikel ilmiah penelitian, bagianmetodologimeliputimetodepenelitian, populasi dan sampel, serta langkah-langkah analisis data. (Arial, 10, spasi 1)

\section{Jenis Penelitian}

Jenis penelitian yang dilakukan dalam penelitian ini adalah penelitian deskriptif kuantitatif, yaitu menjelaskan kondisi keuangan KSPS BMT UGT Sidogiri. Hasil yang diperoleh, diuraikan secara menyeluruh sehingga mendapatkan informasi yang dapat digunakan untuk mengetahui kinerja keuangan KSPS BMT UGT Sidogiri tersebut.

\section{Variabel Penelitian}

Variabel yang di teliti dalam penelitian ini adalah: Rasio likuiditas, Rasio solvabilitas, dan Rasio profitabilitas / Rentabilitas

\section{Definisi Operasional Variabel}

Definisi operasional variabel dalam penelitian ini dapat di jelaskan sebagai berikut:

a. Rasio likuiditas, merupakan rasio yang digunakan untuk menggambarkan kemampuan perusahaan dalam memenuhi kewajiban jangka pendeknya yang segera jatuh tempo. (Hery, 2015:142). Rasio Likuiditas terdiri dari: 1) Current Ratio merupakan rasio untuk mengukur kemampuan perusahaan dalam membayar kewajiban jangka pendeknya (Kasmir, 2014:134). 2) Cash Ratio merupakan rasio yang di gunakan untuk mengukur 
seberapa besar uang kas atau setara kas yang tersedia untuk membayar utang jangka pendek (Hery, 2015:156).

b. Rasio solvabilitas, merupakan rasio yang digunakan untuk menggambarkan kemampuan perusahaan dalam memenuhi seluruh kewajibannya. (Hery, 2015:142). Rasio Solvabilitas terdiri dari: 1) Debt To Asset Ratio merupakan rasio utang yang di gunakan untuk mengukur perbandingan antara total utang dengan total aktiva (Kasmir, 2014:156). 2) Debt To Equity Ratio merupakan rasio yang di gunakan untuk menilai utang dengan ekuitas (Kasmir, 2014:157).

c. Rasioprofitabilitas/ Rentabilitas, merupakan rasio yang digunakan untuk mengukur kemampuan perusahaan dalam menghasilkan laba (Hery, 2015:143). Rasio profitabilitas/Rentabilitas terdiri dari: 1) Return On Equity merupakan rasio yang menunjukkan seberapa besar kontribusi ekuitas dalam menciptakan laba bersih (Hery, 2015:194). 2) Return On Invesment ini sering di sebut ROA (Return On Asset) yang merupakan rasio yang menunjukan seberapa besar kontribusi aset dalam menciptakan laba bersih (Hery, 2015:193).

\section{Metode Pengumpulan Data}

a. Interview

Merupakan metode pengumpulan data dengan melakukan wawancara langsung dengan pemimpin/pemilik serta keryawan yang terlibat secara langsung pada bidang yang diteliti

b. Observasi

Merupakan metode pengumpulan data dengan mengadakan pengamatan secara langsunng pada perusahaan.

c. Studi Literatur

Studi literatur yaitu metode pengumpulan data yang dilakukan dengan cara membaca, mempelajari dan mencatat dari beberapa literatur yang ada hubungannya dengan masalah obyek penelitian.

\section{Jenis Data}

Jenis data yang di gunakan dalam penelitian ini adalah data Sekunder, yaitu data yang di olah oleh perusahaan dan di sajikan dalam bentuk buku Rapat Anggota Tahunan (RAT) yang didalamnya telah tersedia laporan keuangan tahunan perusahaan.

\section{Metode Analisis Data}

Perhitungan dan analisis data di ukur dengan menggunakan rasio keuangan untuk mengetahui kinerja keuangan perusahaan.

1. Rasio Likuiditas

a. Current Ratio $=$

Current Assets x 100\%

Current Liabilities

b. Cash Ratio =

Cash + Bank $\times 100 \%$

Current Liabilities

2. Rasio Solvabilitas

a. Debt To Asset Ratio=

Total Debt $x 100 \%$

Total assets

b. Debt To Equity Ratio=

Total Debt $\times 100 \%$

Total Equity

3. Rasio Profitabilitas/Rentabilitas

a. Return On Investment =

Earning After Tax (EAT) $\times 100 \%$

Total Assets

b. Return On Equity =

Earning After Tax (EAT) $\times 100 \%$

Total Equity

Pembahasan dari hasil perhitungan rasio likuiditas, rasio solvabilitas dan rasio profitabilitas/rentabilitas pada Koperasi Simpan Pinjam Syariah (KSPS) BMT UGT Sidogiri pada tahun 2014 - 2017 adalah sebagai berikut:

1. Rasio Likuiditas

a. Current Ratio

Tabel 4.1: BMT UGT Sidogiri Daftar perhitungan Current Ratio Tahun 2014 2017

\begin{tabular}{|c|c|c|r|}
\hline No & Total Aktiva Lancar & $\begin{array}{c}\text { Total Hutang } \\
\text { Lancar }\end{array}$ & Rasio (\%) \\
\hline 1. & 630.168 .905 .981 & 453.750 .457 .874 & 138,89 \\
\hline
\end{tabular}




\begin{tabular}{|c|c|c|c|}
\hline 2. & 1.017 .340 .460 .998 & 670.129 .663 .772 & 151,81 \\
\hline 3. & 1.438 .999 .824 .206 & 938.813 .122 .155 & 153,28 \\
\hline 4. & 1.800 .334 .330 .581 & 1.177 .458 .137 .246 & 152,90 \\
\hline
\end{tabular}

Sumber data : Laporan RAT Tahun Buku 2014 dan 2017

\section{HASIL DAN PEMBAHASAN}

Pada tahun 2014 dihasilkan rasio sebesar 138,89\%, ini menunjukkan bahwa setiap Rp.100,00,- hutang lancar di jamin dengan Rp.138,89,- aktiva lancar. Tahun 2015 di hasilkan rasio sebesar $151,81 \%$, ini menunjukkan bahwa setiap Rp.100,00,hutang lancar di jamin denganRp.151,81,aktiva lancar. Pada tahun 2016 di hasilkan rasio sebesar $153,28 \%$ ini menunjukkan bahwa setiap Rp.100,00,- hutang lancar di jamin dengan Rp. 153,28,- aktiva lancar. Pada tahun 2017 di hasilkan rasio sebesar $152,90 \%$ ini menunjukkan bahwa setiap Rp.100,00,- hutang lancar di jamin dengan Rp. 152,90,- aktiva lancar. Rasio terbaik berada pada tahun 2016, dan rasio terburuk berada pada tahun 2014 .

Hasil analisis di atas menunjukkan bahwa KSPS BMT UGT Sidogiri mempunyai harta yang cukup likuid dalam membayar kewajiban - kewajiban lancarnya atau di sebut juga dengan likuid. Hal itu dapat di lihat dari perkembangan 4 tahun berturut - turut yang menunjukan angka yang cukup stabil dimana angka yang dihasilkan tidak mengalami fluktuasi yang terlalu signifikan.

b. Cash Ratio

Tabel 4.2 : BMTUGT Sidogiri Daftar perhitungan Cash Ratio Tahun 2014 -

\begin{tabular}{|c|c|c|c|}
\hline No & Kas + Bank & $\begin{array}{c}\text { Total Hutang } \\
\text { Lancar }\end{array}$ & Rasio (\%) \\
\hline 1. & 144.265 .463 .324 & 453.750 .457 .874 & 31,79 \\
\hline 2. & 253.887 .622 .641 & 670.129 .663 .772 & 37,89 \\
\hline
\end{tabular}

\begin{tabular}{|c|c|c|c|}
\hline 3. & 220.825 .296 .471 & 938.813 .122 .155 & 23,52 \\
\hline 4. & 278.778 .869 .248 & 1.177 .458 .137 .246 & 23,68 \\
\hline
\end{tabular}

Sumber data : Laporan RAT Tahun Buku 2014 dan 2017

Pada tahun 2014 dihasilkan rasio sebesar 31,79\%, ini menunjukkan bahwa setiap Rp.100,00,- hutang lancar di jamin dengan Rp.31,79,- kas dan Bank untuk memenuhi kewajibannya. Pada tahun 2015 dihasilkan rasio sebesar $37,89 \%$, ini menunjukkan bahwa setiap Rp.100,00,hutang lancar di jamin dengan Rp.37,89,kas dan Bank untuk memenuhi kewajibannya. Pada tahun 2016 dihasilkan rasio sebesar $23,52 \%$, ini menunjukkan bahwa setiap Rp.100,00,- hutang lancar di jamin dengan Rp.23,52,- kas dan Bank untuk memenuhi kewajibannya. Pada tahun 2017 dihasilkan rasio sebesar 23,68\%, ini menunjukkan bahwa setiap Rp.100,00,hutang lancar di jamin dengan Rp.23,68,kas dan Bank untuk memenuhi kewajibannya. Rasio terbaik berada pada tahun 2015, dan rasio terburuk berada pada tahun 2016. Hasil perhitungan rasio

menunjukkan angka yang berfluktuasi dan cenderung mengalami penurunan angka rasio. Pada perhitungan Cash Ratio menghasilkan angka yang sangat kecil, hal ini di sebabkan karena pada analisis tersebut tidak melibatkan akun piutang, sedangkan KSPS BMT UGT Sidogiri ini bergerak dalam bidang simpan pinjam dimana sebagian besar aktivanya di peroleh dari hasil perputaran pinjaman yang diberikan koperasi kepada para nasabahnya. Analisis Cash Ratio ini menunjukkan bahwa kas dan setara kas yang dimiliki koperasi tidak cukup dalam membayar hutang lancarnya, keadaan ini sering disebut juga dengan istilah illikuid.

Rasio Solvabilitas

a. Debt To Asset Ratio

Tabel 4.3: BMT UGT Sidogiri Daftar perhitungan Debt To Asset Ratio Tahun 
$2014-2017$

\begin{tabular}{|c|c|c|c|}
\hline No & Total Hutang & Total Aktiva & $\begin{array}{c}\text { Rasio } \\
(\%)\end{array}$ \\
\hline 1. & 536.437 .712 .617 & 662.771 .142 .563 & 80,94 \\
\hline 2. & 831.386 .343 .062 & 1.069 .163 .194 .251 & 77,77 \\
\hline 3. & 1.172 .786 .123 .589 & 1.509 .559 .920 .750 & 77,69 \\
\hline 4. & 1.510 .769 .095 .492 & 1.892 .158 .724 .834 & 79,84 \\
\hline
\end{tabular}

Sumber data : Laporan RAT Tahun Buku 2014 dan 2017

Pada tahun 2014 rasio yang dihasilkan adalah sebesar $80,94 \%$, ini menunjukkan bahwa setiap Rp.80,94,- hutang di jamin dengan Rp.100,00,- asset / aktiva. Pada tahun 2015 rasio yang dihasilkan adalah sebesar $77,77 \%$, ini menunjukkan bahwa setiap Rp.77,77,- hutang di jamin dengan Rp.100,00,- asset / aktiva. Pada tahun 2016 rasio yang dihasilkan adalah sebesar $77,69 \%$, ini menunjukkan bahwa setiap Rp.77,69,- hutang di jamin dengan Rp.100,00,- asset / aktiva. Pada tahun 2017 rasio yang dihasilkan adalah sebesar $79,84 \%$, ini menunjukkan bahwa setiap Rp.79,84,- hutang di jamin dengan Rp.100,00,- asset / aktiva. Rasio terbaik berada pada tahun 2015, dan rasio terburuk berada pada tahun 2014 .

hasil perhitungan menunjukkan angka yang berfluktuasi dan cenderung naik hanya saja pada tahun 2017 mengalami sedikit penurunan angka rasio sebesar 2,51\%. Pada perhitungan Debt To Asset Ratio ini semakin kecil hasil rasio maka semakin baik kinerja perusahaan, Karena menunjukkan bahwa aset koperasi mampu memberikan kontribusi yang cukup terhadap total hutang yang semakin kecil.

b. Debt To Equity Ratio

Tabel 4.4: BMT UGT Sidogiri Daftar perhitungan Debt To Equity Ratio Tahun $2014-2017$

\begin{tabular}{|c|c|c|c|}
\hline No & Total Hutang & Total Modal & $\begin{array}{c}\text { Rasio } \\
(\%)\end{array}$ \\
\hline
\end{tabular}

\begin{tabular}{|c|c|c|c|}
\hline 1. & 536.437 .712 .617 & 126.333 .429 .947 & 42,47 \\
\hline 2. & 831.386 .343 .062 & 237.776 .851 .189 & 34,97 \\
\hline 3. & 1.172 .786 .123 .589 & 336.773 .797 .160 & 34,82 \\
\hline 4. & 1.510 .769 .095 .492 & 381.389 .629 .341 & 39,61 \\
\hline
\end{tabular}

Sumber data : Laporan RAT Tahun Buku 2014 dan 2017

Pada tahun 2014 rasio yang dihasilkan adalah sebesar $42,47 \%$, ini menunjukkan bahwa setiap Rp.42,47,- hutang di jamin dengan Rp.100,00,- modal yang di tanamkan. Pada tahun 2015 rasio yang dihasilkan adalah sebesar 34,97\%, ini menunjukkan bahwa setiap Rp.34,97,hutang di jamin dengan Rp.100,00,- modal yang di tanamkan. Pada tahun 2016 rasio yang dihasilkan adalah sebesar 34,82\%, ini menunjukkan bahwa setiap Rp.34,82,hutang di jamin dengan Rp.100,00,- modal yang di tanamkan. Pada tahun 2017 rasio yang dihasilkan adalah sebesar 39,61\%, ini menunjukkan bahwa setiap Rp.39,61,hutang di jamin dengan Rp.100,00,- modal yang di tanamkan. Rasio terbaik berada pada tahun 2016, dan rasio terburuk berada pada tahun 2014. Hasil perhitungan menunjukkan angka yang berfluktuasi dan cenderung naik hanya saja pada tahun 2017 mengalami sedikit penurunan angka rasio sebesar 4,79\%. Pada perhitungan Debt To Equity Ratio ini semakin kecil hasil rasio maka semakin baik kinerja perusahaan, Karena menunjukkan bahwa modal yang ditanamkan mampu memberikan kontribusi yang cukup terhadap total hutang yang semakin kecil.

2. Rasio Profitabilitas/Rentabilitas

a. Return On Equity

Tabel 4.5: BMT UGT Sidogiri Daftar perhitungan Return On Equity Tahun $2014-2017$

\begin{tabular}{|c|c|c|c|}
\hline No & $\begin{array}{c}\text { Laba Bersih } \\
\text { Usaha }\end{array}$ & Total Modal & $\begin{array}{c}\text { Rasio } \\
(\%)\end{array}$ \\
\hline
\end{tabular}




\begin{tabular}{|c|c|c|c|}
\hline 1. & 32.716 .977 .343 & 126.333 .429 .947 & 25,90 \\
\hline 2. & 60.315 .433 .637 & 237.776 .851 .189 & 25,37 \\
\hline 3. & 68.730 .685 .881 & 336.773 .797 .160 & 20,41 \\
\hline 4. & 72.471 .936 .569 & 381.389 .629 .341 & 19,00 \\
\hline
\end{tabular}

Sumber data : Laporan RAT Tahun Buku 2014 dan 2017

Pada tahun 2014 dihasilkan rasio sebesar 25,90\%, ini menunjukkan bahwa setiap Rp.100,00,- modal yang di tanamkan menghasilkan Rp.25,90,- SHU atau Laba bersih usaha. Pada tahun 2015 dihasilkan rasio sebesar $25,37 \%$, ini menunjukkan bahwa setiap Rp.100,00,- modal yang di tanamkan menghasilkan Rp.25,37,- SHU atau Laba bersih usaha. Pada tahun 2016 dihasilkan rasio sebesar 20,41\%, ini menunjukkan bahwa setiap Rp.100,00,modal yang di tanamkan menghasilkan Rp.20,41,- SHU atau Laba bersih usaha. Pada tahun 2017 dihasilkan rasio sebesar $19,00 \%$, ini menunjukkan bahwa setiap Rp.100,00,- modal yang di tanamkan menghasilkan Rp.19,00,- SHU atau Laba bersih usaha. Rasio terbaik berada pada tahun 2014, dan rasio terburuk berada pada tahun 2017. Hasil analisis tersebut menunjukkan bahwa modal yang di miliki koperasi cukup rentabel dalam menghasilkan sisa hasil usaha yang maksimal, hal ini di tunjukkan dari hasil analisis yang menghasilkan angka - angka rasio yang cukup baik.

b. Return On Invesment

Tabel 4.6: BMT UGT Sidogiri Daftar perhitungan Return On Invesment Tahun $2014-2017$

\begin{tabular}{|c|c|c|l|}
\hline No & $\begin{array}{c}\text { Laba Bersih } \\
\text { Usaha }\end{array}$ & Total Aktiva & Rasio (\%) \\
\hline 1. & 32.716 .977 .343 & $\begin{array}{c}662.771 .142 .5 \\
63\end{array}$ & 4,97 \\
\hline 2. & 60.315 .433 .637 & $\begin{array}{c}1.069 .163 .194 \\
251\end{array}$ & 5,64 \\
\hline
\end{tabular}

\begin{tabular}{|c|c|c|l|}
\hline 3. & 68.730 .685 .881 & $\begin{array}{c}1.509 .559 .920 . \\
750\end{array}$ & 4,55 \\
\hline 4. & 72.471 .936 .569 & $\begin{array}{c}1.892 .158 .724 . \\
834\end{array}$ & 3,83 \\
\hline
\end{tabular}

Sumber data : Laporan RAT Tahun Buku 2014 dan 2017

Pada tahun 2014 dihasilkan rasio sebesar $4,97 \%$, ini menunjukkan bahwa setiap Rp.100,00,- aktiva yang di miliki dapat menghasilkan Rp.25,90,- SHU atau Laba bersih usaha. Pada tahun 2015 dihasilkan rasio sebesar 5,64\%, ini menunjukkan bahwa setiap Rp.100,00,aktiva yang di miliki dapat menghasilkan Rp.5,64,- $\quad$ SHU atau Laba bersih usaha. Pada tahun 2016 dihasilkan rasio sebesar $4,55 \%$, ini menunjukkan bahwa setiap Rp.100,00,- aktiva yang di miliki dapat menghasilkan Rp.4,55,- SHU atau Laba bersih usaha. Pada tahun 2017 dihasilkan rasio sebesar 3,83\%, ini menunjukkan bahwa setiap Rp.100,00,- aktiva yang di miliki dapat menghasilkan Rp.3,83,- SHU atau Laba bersih usaha. Rasio terbaik berada pada tahun 2015, dan rasio terburuk berada pada tahun 2017. pada analisis Return On Invesment dari tahun 2012-2015 menghasilkan angka rasio berturut - turut $4,97 \%, 5,64 \%, 4,55 \%, 3,83 \%$, dimana dari tahun ketahun keempat rasio tersebut cenderung mengalami penurunan angka rasio tetapi masih menunjukkan angka yang cukup baik. Hal ini di sebabkan karena koperasi mampu menggunakan aktivanya secara produktif walaupun dari tahun 2014 hingga 2017 terjadi penurunan laba bersih usaha di bandingkan dengan total aktiva yang ada, tetapi masih mampu menghasilkan laba bersih usaha yang maksimal atau dengan kata lain koperasi menunjukkan rentabilitas ekonomi yang cukup baik atau cukup rentabel.

\section{KESIMPULAN}

Berdasarkan hasil perhitungan kinerja keuangan perusahaan dengan menggunakan beberapa alat analisis antara lain : Rasio 
Likuiditas, Rasio Solvabilitas, dan Rasio rofitabilitas/ Rentabilitas, maka dapat di tarik kesimpulan sebagai berikut:

a. Analisis Likuiditas pada KSPS BMT UGT Sidogiri menunjukkan angka yang cukup baik atau likuid pada analisis Current Ratio, angka rasio dari tahun 2014 - 2017 yaitu 138,89\%, 151,81\%, $153,28 \%$ dan $152,90 \%$, dari tahun ketahun keempat rasio tersebut cenderung mengalami peningkatan angka rasio walaupun pada tahun 2017 terjadi penurunan Current Ratio yang disebabkan karena terjadi kenaikan hutang lancar yang cukup tinggi. Sedangkan pada analisis Cash Ratio dari tahun ke tahun angka yang di hasilkan berfluktuasi dan cenderung mengalami penurunan angka rasio, angka rasio dari tahun $2014-2017$ yaitu 31,79\%, $37,89 \%, 23,52 \%$, dan 23,68\%, Hal ini menunjukkan bahwa kas dan setara kas yang dimiliki koperasi tidak cukup dalam membayar hutang lancarnya, keadaan ini sering di sebut dengan istilah illikuid.

b. Analisis Solvabilitas pada Koperasi KSPS BMT UGT Sidogiri menunjukkan angka yang cukup baik atau solvabel pada analisis Debt To Asset Ratio, angka rasio dari tahun $2014-2017$ yaitu $80,94 \%, 77,77 \%, 77,69 \%$ dan 79,84\%, hal ini menunjukkan bahwa aset koperasi mampu memberikan kontribusi yang cukup terhadap total hutang yang dimiliki. Sedangkan pada analisis Debt To Equity Ratio dari tahun ke tahun angka yang di hasilkan berfluktuasi dan cenderung mengalami peningkatan, angka rasio dari tahun 2014 - 2017 yaitu $42,47 \%, 34,97 \%, 34,82 \%$, dan 39,61\%, hal ini menunjukkan bahwa modal yang di tanamkan mampu memberikan kontribusi yang cukup terhadap total hutang

c. Analisis Profitabilitas pada KSPS BMT UGT Sidogiri menunjukkan angka yang cukup baik atau rentabel pada analisis Return On Equity, angka rasio dari tahun 2014 - 2017 yaitu 25,90\%, 25,37\%, $20,41 \%$ dan $19,00 \%$, dari tahun ketahun keempat rasio tersebut cenderung mengalami penurunan angka rasio, namun angka rasio yang di hasilkan masih menunjukkan angka yang cukup baik karena modal yang di miliki koperasi cukup rentabel dalam menghasilkan sisa hasil usaha yang maksimal. Sedangkan pada analisis Return On Investment dari tahun ke tahun angka yang di hasilkan berfluktuasi dan cenderung mengalami penurunan angka rasio, angka rasio dari tahun 2014 - 2017 yaitu 4,97\%, 5,64\%, 4,55\%, dan $3,83 \%$, namun angka rasio yang di hasilkan menunjukkan angka yang cukup baik atau cukup rentabel karena koperasi masih mampu menghasilkan laba bersih usaha yang maksimal.

\section{SARAN}

Melihat analisis yang telah dilakukan, maka peneliti memberikan saran yang mungkin dapat dijadikan masukan untuk memperbaiki perkembangan perusahaan dari tingkat likuiditas, solvabilitas, dan profitabilitas/ rentabilitas ekonomi. Saran yang mungkin dapat dijadikan masukan yaitu:

a. Mempertinggi tingkat Likuiditas perusahaan dengan cara:

1) Dengan hutang lancar tertentu, diusahakan untuk menambah aktiva lancar;

2) Dengan aktiva lancar tertentu, diusahakan untuk mengurangi hutang lancar;

3) Dengan hutang lancar tertentu, diusahakan untuk menambah kas;

4) Dengan kas tertentu, diusahakan untuk mengurangi hutang lancar.

b. Menekan tingkat Solvabilitas perusahaan dengan cara: 
1) Menambah aktiva tanpa menambah hutang;

2) Menambah modal sendiri tanpa menambah hutang.

c. Mempertinggi

Profitabilitas/Rentabilitas perusahaan dengan cara:

1) Meningkatkan laba bersih usaha tanpa menambah modal yang terlalu banyak;

2) Meningkatkan laba bersih usaha tanpa menambah aktiva yang terlalu banyak.

d. Sebaiknya Koperasi Simpan Pinjam Syariah (KSPS) BMT UGT Sidogiri senantiasa melakukan analisis rasio keuangan secara periodik, hal ini dilakukan agar mengetahui sejauh mana kinerja koperasi yang telah dilakukan dan untuk pertimbangan manajemen dalam mengambil keputusan dan kebijakan yang akan diambil pada tahun - tahun berikutnya.

\section{DAFTAR PUSTAKA}

Afiyanti, Dwi. 2013. Analisis Rasio Keuangan Sebagai Alat Untuk Mengukur Kinerja Keungan Pada UD. Barokah Putra Jaya Di Sumberan Ambulu Jember. Jember: STIE Mandala Jember.

Departemen Agama RI. 2004. AlJumanatul 'Ali Al-Qur'an dan Terjemahannya. Bandung: J-ART

Hartiji, Agus dan Martono.2007. Rasio Keuangan. Jakarta: BPFE Hery. 2015. Analisis Kinerja Manajemen. Jakarta: PT Grasindo. http://bmtugtsidogiri.co.id/tentangkami-9.html 25 Desember 2015, 18.35

http://lib.uin-malang.ac.id. 23 Oktober $2015,18: 38$

http://www.google.com/url?q=http://eprints .ums.ac.id/26914/15/02._Artikel_P ublikasi - Erlina_Yutikawati. 23 Oktober 2015, 18:20

James G. Van Horne dan Wachowicz,
John M. 2014. Prinsip Prinsip Manajemen Keuangan. Edisi Ketigabelas. Jakarta : Salemba Empat

Kasmir. 2014. Analisis Laporan Keuangan.

Edisi 1. Cetakan Ketujuh. Jakarta: Rajawali Pers.

Munawir. 2006. Analisis Laporan Keuangan. Yogyakarta : Liberty

Munawir, S.2008. Analisis Laporan Keuangan. Edisi Keempat. Yogyakarta: Liberty.

Nilasari, Fita. 2008. Analisis rasio keuangan sebagai alat penilaian untuk mengukur kinerja keuangan pada PT.Unilever Indonesia Tbk. Malang: Universitas Islam Negeri (UIN) Malang.

Ni'mah, Ulin.2011. Analisis Kinerja Keuangan Pada Koperasi BMT Bina Usaha Kecamatan Bergas Kabupaten Semarang. Semarang: Universitas Negeri Semarang (UNNES).

Rapat Anggota Tahunan KSPS BMT UGT SIDOGIRI INDONESIA Tahun Buku 2014 dan 2016. 